\title{
EL NO-DO COMO MEDIO DE CONSTRUCCIÓN DE LA IDENTIDAD FEMENINA (1943-1975)
}

\section{The NO-DO as a means of female identity development (1943-1975)}

\section{María Dolores Molina Poveda ${ }^{\alpha}$}

Fecha de recepción: 22/11/2019 • Fecha de aceptación: 28/02/2020

Resumen. El régimen franquista retornó a unos postulados conservadores, en lo referente a la feminidad, que pretendían devolver a la mujer al ámbito privado. Estos principios fueron transmitidos por diversos organismos e instituciones como la Sección Femenina, Auxilio Social y los centros educativos. No obstante, el régimen utilizó otros medios para difundir su doctrina. NO-DO (NOticiarios-DOcumentales) fue uno de los más emblemáticos, ya que permitía a toda la población, independientemente de la clase social, sexo y nivel de alfabetización, comprender el mensaje. En este estudio hemos utilizado NO-DO como fuente principal para conocer qué y cómo transmitió el régimen sus principios sobre la feminidad. Para ello hemos recurrido a las noticias, documentales y reportajes - pertenecientes a la sección de Noticiarios, Documentales en Blanco y Negro y en Color, Revista de Imágenes e Imágenes del Deporte- sobre la educación femenina. Capacitar a la mujer para realizar las labores del hogar, cuidar a los hijos, ser una esposa sumisa y abnegada y una buena cristiana fue la identidad que NO-DO transmitió sobre la mujer. Además, este medio audiovisual también mostró otra identidad, la de las mujeres de la Sección Femenina que trabajaban formando a las niñas, jóvenes y adultas en la doctrina nacionalsindicalista y católica.

Palabras clave: Identidad femenina; NO-DO; Sección Femenina; Auxilio Social; Educación.

Abstract. Franco's regime undertook a reversion to certain conservative ideas relating to femininity in an effort to return women to the private sphere. These principles were transmitted by various organizations and institutions such as the Sección Femenina, Auxilio Social and educational centres. However,

\footnotetext{
a Departamento de Teoría e Historia de la Educación y M.I.D.E. Universidad de Málaga. Bulevar Louis Pasteur, 25, 29010 Málaga. España. lolamolina1993@hotmail.com (D) https://orcid.org/00000002-8535-9738
}

Cómo citar este artículo: Molina Poveda, María Dolores. «El NO-DO como medio de construcción de la identidad femenina». Historia y Memoria de la Educación 12 (2020): 239-270 
the regime used other means to spread its doctrine as well. NO-DO (NOticiarios-DOcumentales, News Program - Documentaries) was one of the most emblematic since it allowed the entire population, regardless of social class, sex or literacy level, to capture its message. In this study, we have used NO-DO as the main source for discovering how the regime transmitted its principles about femininity and what these principles were. We have reviewed news, documentaries and reports -included in different sections: News, Black and White and Colour documentaries, Sport Image Magazine and Images - where references to women's education were made. Training women for housework and childcare, for being submissive and dutiful wives and good Christians; this was the identity that NO-DO conveyed about the woman's role. NO-DO displayed another identity as well: that of women working for the Sección Femenina training girls, youth and adults in the national syndicalist and Catholic doctrine.

Keywords: Female Identity; NO-DO; Sección Femenina; Auxilio Social; Education.

\section{INTRODUCCIÓN}

El estudio de las relaciones de género desde diferentes perspectivas ha sido uno de los temas cada vez más tratados en las últimas décadas, ya que desde los siglos XIX y XX comenzó a cuestionarse la ancestral idea de que el hombre era superior a la mujer. Falcone define el concepto de género como «una construcción cultural que rige las relaciones entre los sexos y los códigos normativos y valores a partir de los cuales se establecen los criterios que permiten hablar de lo masculino y lo femenino e incluso de unas relaciones de poder» catalogadas como «asimétricas y subordinadas». ${ }^{1}$ Las funciones asignadas a los hombres y a las mujeres no surgen de la realidad biológica y psicológica de cada sexo, sino que son estipuladas por la sociedad atendiendo a las creencias culturales que se han heredado y legitimado por, fundamentalmente, dos vías principales: la religión y la razón. La importancia de estudiar y conocer los prototipos de género radica en que «las construcciones simbólicas y discursivas, compartidas socialmente, [son las que] establecen las posibilidades y los límites que se abren a los sujetos históricos, y por lo tanto determinan la acción, así como las expectativas o deseos de los

\footnotetext{
1 Rosa Falcone, «Género, familia y autoridad. Sociedades patriarcales y comunidades contemporáneas», Revista Científica de UCES XVI, no. 1 (2012): 68. http://dspace.uces.edu.ar:8180/xmlui/bitstream/handle/123456789/1465/Genero_familia_Falcone.pdf?sequence=1.
} 
mismos».2 Teniendo en cuenta estos aspectos, en el presente trabajo se va a abordar que mostró el franquismo sobre la educación femenina a través de su medio propagandístico audiovisual más emblemático, NODO (1943-1975), y qué identidad femenina quería el régimen transmitir a través de dichas noticias, documentales y reportajes para que las mujeres la adoptasen como propia.

La Guerra Civil no solo enfrentó a personas de dos bandos, sino que también enfrentó valores, ideales, doctrinas e identidades. El franquismo no aceptaba los cambios producidos a comienzos del siglo XX en torno al papel de la mujer en la sociedad y que condujeron a la denominada "mujer moderna», como tampoco aceptó «la igualdad de derechos y deberes para todos los ciudadanos sin distinción de sexo, filiación y religión» ni «la incorporación de la mujer en la vida pública» ${ }^{3}$ reconocidos por la Segunda República. No obstante, las mujeres que pudieron acceder a esta «liberación» de lo tradicionalmente impuesto fueron, fundamentalmente, las de clase media. Con la llegada del franquismo, las españolas se encontraron con una serie de consignas y medidas que negaban la igualdad entre hombres y mujeres al afirmar que éstas eran seres débiles y frágiles dotadas de sacrificio, delicadeza, paciencia y abnegación. Estas cualidades solo las capacitaban para desempeñar labores alejadas del ámbito público y centradas en el hogar y en el cuidado de los hijos, mientras que los hombres sí poseían la capacidad para enfrentarse al mundo que había tras la protección del hogar al estar dotados de energía, fuerza y autoridad.

Finalizada la contienda, el régimen franquista emprendió la gran tarea de construir el nuevo Estado y para ello estableció una doctrina social en la que estipuló cuales debían de ser las funciones de los hombres y de las mujeres, es decir, le otorgó a cada uno una identidad que debían de asumir como propia para servir correctamente a la Patria. Para ello recurrió a la educación y a los medios propagandísticos, al ser estos últimos un arma de persuasión utilizada por un emisor con el fin de influir y adoctrinar a un receptor a través de diferentes canales. En el siglo XX

\footnotetext{
2 Ángela Cenarro Lagunas, «Identidades de género en el catolicismo, el falangismo y la dictadura de Franco (presentación)», Historia y política: Ideas, procesos y movimientos sociales 37 (2017): 18. https://recyt.fecyt.es/index.php/Hyp/article/view/58381/35664.

${ }^{3}$ Anna Balletbó, «La mujer bajo la dictadura», Leviatán 1, no. 8 (1982): 95. https://prensahistorica. mcu.es/es/consulta/registro.cmd?id=1028530
} 
los noticiarios y documentales audiovisuales se consolidaron como un instrumento fundamental para propagar los valores e ideales de diferentes conjuntos de poderes, ya que la imagen y la palabra hablada son entendidas por todos los ciudadanos, independientemente de si saben leer y escribir. Franco vio en ellos un gran potencial y los adoptó para utilizarlos en su propio beneficio creando la entidad Noticiarios y Documentales Cinematográficos «NO-DO». ${ }^{4}$

NO-DO nació a finales de 1942 y perduró hasta 1981. Sus inicios fueron un poco arduos debido a la escasez de medios técnicos y humanos lo que les llevó a firmar un acuerdo con la productora alemana UFA para poder sacar adelante su empresa. ${ }^{5}$ «El día 4 de enero de 1943, los primeros cines de España abrían su programa con la proyección de un material inesperado: un noticiario de unos diez minutos de duración que repasaba lo que ese franquismo ${ }^{6}$ consideraba como actualidad nacional. Las actualidades filmadas pertenecían a la sección de Noticiarios que ostentó el grueso de las noticias filmadas y fue la más relevante de NODO, aunque este organismo también emitió una serie de documentales y reportajes en diferentes secciones como Documentales en Blanco y $\mathrm{Ne}$ gro, Documentales en Color, Revista de Imágenes e Imágenes del Deporte.

NO-DO, según las declaraciones de Joaquín Soriano — primer director de este organismo- nació con la intención de «reflejar todos los aspectos nobles de la vida de nuestra nación: política, económica, artística, cultural, científica, deportiva, etcétera. También estos mismos aspectos, a ser posible, del mundo entero. Debe, en una palabra, informar, instruir y recrear». ${ }^{7}$ Es decir, debía, como rezaba su eslogan, poner «El mundo entero al alcance de todos los españoles». El 17 de diciembre de 1942 se promulgó una orden en la que se disponía la proyección

\footnotetext{
${ }^{4}$ Tranche y Sánchez-Biosca realizaron una de las investigaciones más exhaustivas sobre este medio permitiéndonos conocer su organización, los métodos y tiempos de filmado, producción, distribución y exhibición, entre otros muchos aspectos esenciales para dar vida a los Noticiarios y Documentales. Rafael R. Tranche y Vicente Sánchez-Biosca, NO-DO. El tiempo y la memoria (Madrid: Cátedra/ Filmoteca Española, 2018).

${ }_{5}^{5}$ Saturnino Rodríguez Martínez, El NO-DO: catecismo social de una época (Madrid: Editorial Complutense, 1999).

6 Vicente Sánchez-Biosca, «NO-DO y las celadas del documento audiovisual», Cahiers de civilisation espagnole contemporaine 4 (2009): 2. http://roderic.uv.es/bitstream/handle/10550/29172/059791.pd$\mathrm{f}$ ? sequence $=1$ \&isAllowed $=\mathrm{y}$.

7 Tranche y Sánchez-Biosca, NO-DO, 259.
} 
obligatoria y exclusiva del Noticiario Cinematográfico Español. Esta obligatoriedad se mantuvo hasta 1975 —aunque no dejó de proyectarse hasta 1981 - transmitiendo a los espectadores una gran variedad de noticias, pues NO-DO no fue un organismo dedicado a filmar solo la figura del «generalísimo» y todo lo que le rodeaba, sino que estaba a disposición de todas las delegaciones y organismos oficiales.

La emisión de los noticiarios en las salas cinematográficas antes de la proyección de la película permitió «la educación popular de una ciudadanía con una formación que no sobrepasaba la del nivel escolar», 8 ya que el "cine copaba la atención de los españoles de aquellos difíciles años». ${ }^{9}$ No obstante, NO-DO despertó especial atención entre las mujeres y así lo explicaba Joaquín Soriano quien alegaba que su objetivo era provocar la «máxima sorpresa del espectador», ya que NO-DO «no es más que un periódico cuyo mayor porcentaje de lectores se encuentra en el público femenino; de ahí que dediquemos un especial interés en hacerlo ameno a las mujeres».10 Y para hacerlo más ameno para las mujeres primó la proyección de las noticias sobre temas banales al ser las que más interés despertaban en el sexo femenino. Además, el índice de analfabetismo era mayor entre las mujeres, ${ }^{11}$ lo que propició que NO-DO fuese el medio más idóneo para propagar, de forma directa e indirecta, las actitudes, normas sociales, identidades y valores establecidos por el régimen y que las mujeres debían adoptar y cumplir, convirtiéndose en una herramienta educativa que debe ser estudiada. Teniendo en cuenta todos estos aspectos, en este estudio nos vamos a centrar en conocer qué identidad femenina mostró el franquismo a través de NO-DO (19431975) intentando que las mujeres la asumieran como propia.

Nuestro objetivo principal es conocer aquellas noticias y documentales que NO-DO mostró sobre la educación femenina, y así analizar la identidad femenina impulsada por el nuevo régimen (1943-1975). Sin

\footnotetext{
8 Rodríguez Martínez, El NO-DO, 10.

${ }_{9}$ Rodríguez Martínez, El NO-DO, 10.

10 Tranche y Sánchez-Biosca, NO-DO, 107.

${ }^{11}$ En 1950 las tasas de analfabetismo continuaban siendo elevadas al existir en España un 12\% de hombres y un 22\% de mujeres, mayores de diez años, que no sabían leer ni escribir; Mercedes Vilanova Ribas y Xavier Moreno Juliá, Atlas de la evolución del analfabetismo en España de 1887 a 1981 (Madrid: Ministerio de Educación Cultura y Deporte, 1992), 314-315. https://sede.educacion.gob.es/ publiventa/detalle. action? $\operatorname{cod}=1403$.
} 
embargo, la proyección de una sola realidad, de una sola verdad, en este caso la del régimen, podría convertir esta fuente en poco fiable, ya que la información estaba manipulada para enaltecer unos ideales y que los espectadores los creyesen y asumiesen como propios. Como indican Paz Rebollo y Sánchez Alarcón, «la existencia de falsificaciones o el hecho de que los noticiarios escamoteen en ocasiones la realidad ingrata e intenten sustituirla por otra más deseable no disminuyen su significación testimonial», pues «las reconstrucciones que se incluyen en todas las actualidades cinematográficas tienen el valor de ofrecer una interpretación determinada de un suceso, que ilustra las características de la época».12 NO-DO estuvo vigente desde 1943 hasta 1981, por lo que podemos afirmar que se «convirtió en algo familiar para los españoles de varias generaciones y aún hoy permanece de forma indeleble en el imaginario de todos aquellos que convivieron con él», ${ }^{13}$ convirtiéndolo en una fuente que debe ser estudiada para conocer ese imaginario social y oficial transmitido por el franquismo y visualizado por los ciudadanos.

En 2011 se autorizó la publicación y comercialización de los fondos de NO-DO en la Intranet. Para ello se creó, dentro de la web de RTVE, la página web de Filmoteca Española donde se han publicado y difundido todos los números que componen el archivo de NO-DO. En la página web podemos encontrar diferentes secciones, aunque nosotros nos vamos a centrar en la producción propia de NO-DO: Noticiarios (4011 números); Documentales en Blanco y Negro (216 números); Documentales en Color (495 números); Imágenes del Deporte (88 números); y Revista de Imágenes (1219 números). La selección de aquellos números de NO-DO que trataban sobre la educación femenina se realizó siguiendo una serie de pasos y de filtros: el primero fue el visionado de todos los números que forman cada una de las secciones y la selección de aquellos que tratasen sobre la educación femenina; el segundo fue la creación de una lista de palabras clave que luego fueron introducidas en el buscador y la visualización de los resultados comparándolos con los ya extraídos en el primer paso; y el tercer paso fue la organización de estos números por

\footnotetext{
12 María Antonia Paz Rebollo y María Inmaculada Sánchez Alarcón, «La historia filmada: los noticiarios cinematográficos como fuente histórica. Una propuesta metodológica», Filmhistoria online 9 , no. 1 (1999): 20. http://revistes.ub.edu/index.php/filmhistoria/article/view/12366

13 Vicente Sánchez-Biosca, «NO-DO, icono del franquismo», Letra internacional 88 (2005): 29. http:// roderic.uv.es/handle/10550/29197.
} 
categorías (Sección Femenina, Auxilio Social y Educación Formal) y subcategorías.

De la categoría de Sección Femenina se hallaron un total de 143 noticias, documentales y reportajes; ${ }^{14}$ de Auxilio Social se emitieron un total de 41 noticias, documentales y reportajes, de los cuales 14 trataban sobre la educación femenina; y de la Educación Formal se proyectaron 390 noticias, documentales y reportajes, de los que 128 trataban sobre la educación femenina o mostraban la presencia de mujeres en las aulas desde la década de los cuarenta hasta la primera mitad de los años setenta. La información extraída de cada número ha sido recogida en una ficha de observación para facilitar su análisis posterior. Los apartados que componen la ficha son: sección de NO-DO a la que pertenece la noticia, documental o reportaje (Noticiarios, Documental en Blanco y Negro, Documental en Color, Revista de Imágenes e Imágenes del Deporte); número y fecha de publicación del número cinematográfico; minuto en el que aparece la escena educativa; nombre de la institución donde se desarrolla la escena y ubicación; descripción de todo lo que acontece en la escena educativa; y narración. Las noticias filmadas y proyectadas por NO-DO se caracterizaban porque la narración era una reiteración de lo que las imágenes mostraban, además de encontrar muchas similitudes entre unas noticias y otras de similar temática. Como establece Sorlin, ${ }^{15}$ no solo nos tenemos que fijar en los detalles de las imágenes cinematográficas, sino que también debemos observar el conjunto, por lo que en este estudio se escogerán aquellas afirmaciones, locuciones e imágenes de los noticiarios y documentales que mejor engloben lo que el franquismo quería transmitir sobre la educación y la identidad femenina.

\section{SER MUJER EN EL FRANQUISMO: LA ETERNA AUSENTE}

El régimen franquista retornó a unos postulados conservadores, en lo referente a la feminidad, devolviendo a la mujer al ámbito privado y

\footnotetext{
14 Diez noticias corresponden a la subcategoría de Albergues femeninos; 29 a la de Coros y Danzas; nueve a la de Cátedras Ambulantes; diez noticias a la de gimnasia y deportes; 33 a la subcategoría de Cursos para mujeres y Escuelas de mandos e instructoras de la Sección Femenina; 29 a la de consejos y concentraciones nacionales; y 20 noticias a la subcategoría de Otras Actividades en la que se encuadran las exposiciones, compañía de teatro «Los títeres», etc.

15 Pierre Sorlin, Cines europeos, sociedades europeas 1939-1990 (Barcelona: Paidós Comunicación, 1996).
} 
despojándola de los avances alcanzados en el primer tercio del siglo XX. La identidad femenina que promulgaron se basaba en ser madre, esposa, ama de casa y cristiana. Estos principios no solo los adquirían las niñas en sus casas, pues las escuelas y los diversos centros instalados por la Sección Femenina y Auxilio Social también se encargaban de dicha labor. Aunque la posibilidad, abierta a las mujeres en 1910, de acceder a estudios medios, técnicos y superiores se mantuvo - en teoría -, en la posguerra el ritmo de matriculaciones se frenó considerablemente. Las mujeres que trabajaban en las fábricas lo hacían sin cualificación, por lo que ocupaban los puestos profesionales más bajos. El nuevo régimen se centró en la capacitación rural de la mujer como una extensión de sus tareas domésticas y no como un trabajo, siendo impulsada por la Sección Femenina a través de las Cátedras Ambulantes, de las instructoras rurales y de la Hermandad de la Ciudad y el Campo. La instrucción que se ofrecía a las mujeres estaba enfocada a los estudios artísticos, artesanales, economía doméstica, corte y confección, cocina, puericultura, nacionalsindicalismo, catolicismo, educación física, música y danzas; en definitiva, enseñanzas que sí guardaban, según el nuevo régimen, relación con las tareas naturales del sexo femenino y que les permitirían desarrollarlas de manera eficaz.

No obstante, Sánchez Blanco destaca que «se concedía a la mujer la posibilidad de decidir «su destino» en función de «su vocación personal». ${ }^{16}$ Es decir, a las mujeres se les ofrecían tres opciones: el matrimonio y el cuidado de los hijos, la vida religiosa, y la de poder cursar estudios profesionales o superiores y ejercer una profesión siendo este camino transitado solo por las mujeres solteras, aunque la existencia de mujeres trabajadoras, casadas y madres - principalmente de clases populares - también era una realidad, aunque el franquismo pretendiese negar esta evidencia. La feminidad impuesta por el régimen franquista estuvo fundamentada en el retorno a las ideas y a la pedagogía del siglo XIX en el que el sentimiento patriótico-religioso «fomentaba la fidelidad a los principios de la ortodoxia religiosa como soporte de la conciencia nacional» ${ }^{17}$ Esta influencia

\footnotetext{
${ }^{16}$ Laura Sánchez Blanco, «El boletín de Auxilio Social. La formación de las mujeres que trabajaban en el servicio social (1937-1939)», Papeles Salmantinos de Educación 17 (2013): 113. https://summa. upsa.es/viewer.vm?id=0000032528\&page $=1 \&$ search=\&lang=es\&view=main .

17 Teresa Rabazas Romero y Sara Ramos Zamora, «La construcción del género en el franquismo y los discursos educativos de la Sección Femenina», Encounters on education = Encuentros sobre
} 
de la Iglesia, de la religión católica, supuso la separación de ambos sexos en el ámbito educativo y en diversas actividades sociales con el fin de aumentar el sentimiento de pecaminosidad producido por la relación entre hombre-mujer y de enaltecer la figura del hombre sobre la mujer, pues las funciones naturales de ésta eran permanecer en el ámbito privado cuidando de sus hijos y cualquier actividad realizada fuera de este espacio y de sus labores por mero placer era catalogada como pecado. ${ }^{18}$

La segregación por sexos en los colegios fue la nota dominante y así apareció reflejada en NO-DO, aunque se proyectó un número muy escaso de noticias sobre la Educación Primaria. ${ }^{19}$ En los colegios se transmitieron estos principios de identidad femenina a través de un currículo femenino con el que se pretendía formar «una profesional del hogar y de la familia». ${ }^{20}$ En los diferentes números emitidos por NO-DO, las niñas siempre aparecían en centros o en aulas separadas de los niños, mientras eran instruidas en enseñanzas diferentes o impartidas desde otra óptica a la que cursaban los muchachos como, por ejemplo, la alimentación. «Las niñas reciben nociones sobre nutrición. [...] Otras, ya mayorcitas, estudian la composición de los alimentos y la mejor forma de aprovecharlos en la economía doméstica. No cabe duda de que todas ellas concluirán siendo excelentes amas de casa». ${ }^{21}$ Las noticias emitidas por NO-DO también presentaron a las niñas dibujando, realizando ejercicios gimnásticos, etc., aunque también predominaron las noticias en las que Franco u otras autoridades visitaban estos centros. La Ley General de Educación de 1970 instauró el acceso de las mujeres, «en igualdad», al sistema de enseñanza obligatoria, aunque la realidad en muchos centros continuó inmóvil. Sin embargo, en un Noticiario de 1972 se informó a los españoles de que la Escuela del Mar de Barcelona era

\footnotetext{
educación = Recontres sur l'éducation 7 (2006): 47. https://dialnet.unirioja.es/servlet/articulo?codigo=4683187.

18 Eloy Terrón Abad, «Coeducación y control social en la España de la Posguerra», Revista de educación 326 (2001): 185-194. http://www.educacionyfp.gob.es/dam/jcr:c17dc2c6-e377-4a04-a2d168893f9adb3c/re32611-pdf.pdf .

19 NO-DO proyectó 48 noticias, documentales y reportajes sobre la Educación Primaria y en algunas de ellas (ocho en las décadas de los cuarenta y de los cincuenta y 12 en los años sesenta hasta mediados de los setenta) mostraron a niñas en colegios de Educación Primaria.

20 Rabazas Romero y Ramos Zamora, «La construcción del género», 47.

${ }^{21}$ Revista de Imágenes n. 1204 (01/01/1968).
} 
un centro mixto y experimental «en la que todos los métodos pedagógicos van encaminados a descubrir y potenciar la personalidad del alumno». ${ }^{22}$ Las imágenes transmitieron a niños y niñas asistiendo juntos a clase y jugando en equipo, aunque sí había una actividad manual que solo era realizada por las alumnas, la cestería.

Al contrario de lo que sucedió en los números de NO-DO sobre la Educación Primaria, la ausencia de la mujer en los noticiarios, documentales y reportajes emitidos por NO-DO sobre la Enseñanza Media ${ }^{23}$ y Universitaria ${ }^{24}$ fue la tónica dominante hasta las décadas de los sesenta y los setenta. Con respecto a la Enseñanza Media, NO-DO mostró a las alumnas en las aulas; o realizando una exhibición de danzas o de ejercicios gimnásticos ante un grupo de autoridades que visitaron los diferentes institutos. Las estudiantes universitarias también tuvieron una escasa presencia en NO-DO hasta esas décadas. Las imágenes que predominaron en NO-DO, en los cuarenta y los cincuenta, sobre universitarias fueron las de mujeres extranjeras, junto a sus compañeros varones, realizando cursos de verano en diferentes universidades españolas, la entrega de diplomas o asistiendo a actos celebrados en la universidad. Esta imagen se mantuvo durante los años sesenta y hasta mediados de los setenta, aunque hubo un aumento de noticias que mostraron a la mujer española en la universidad y en las residencias universitarias femeninas.

En 1943 se promulgó una orden por la que se creó la Sección de Enseñanzas Profesionales de la mujer, dentro de la Junta Central de Formación Profesional, con la finalidad de «dar una orientación puramente femenina a las enseñanzas profesionales de la mujer». ${ }^{25}$ Esta normativa

\footnotetext{
${ }^{22}$ Noticiario $n .^{\circ} 1558$ A $(13 / 11 / 1972)$.

${ }_{23}$ De 11 noticias que se emitieron entre la década de los cuarenta y de los cincuenta sobre Enseñanza Media, solo tres mostraron a alumnas de este nivel educativo; mientras que en la década de los sesenta y hasta mediados de los setenta se proyectaron cinco noticias, documentales y reportajes de la Enseñanza Media femenina de las 12 que se emitieron sobre este nivel.

${ }^{24}$ De 80 noticias que se emitieron entre la década de los cuarenta y de los cincuenta sobre Enseñanza Universitaria, 16 mostraron la presencia de mujeres en las Universidades; mientras que en la década de los sesenta y hasta mediados de los setenta, de las 47 noticias, documentales y reportajes que se proyectaron sobre Enseñanza Universitaria, 27 mostraron la presencia de mujeres en estos centros.

25 Orden por la que se crea, en la actual Junta Central de Formación Profesional, la Sección de Enseñanzas Profesionales de la Mujer, Boletín Oficial del Estado, 29 de noviembre de 1943, núm. 333, 11472-11473. https://www.boe.es/datos/pdfs/BOE//1943/333/A11472-11473.pdf.
} 
continuó con lo ya establecido en las disposiciones anteriores sobre la formación femenina manteniendo las Escuelas de Comercio, las de Artes y Oficios - entre otras que fueron surgiendo bajo la dirección de la Sección Femenina, la Obra Sindical de Artesanía, centros privados...y las enfocadas a la educación propia del sexo femenino - Escuelas Hogar de la Sección Femenina o el Instituto de Enseñanzas Profesionales de la Mujer (Madrid)—. Los noticiarios y documentales que NO-DO emitió durante los años cuarenta y cincuenta no mostraron la presencia de mujeres en las aulas, excepto en aquellas en las que se impartían especialidades vinculadas con la artesanía o las enseñanzas artísticas. ${ }^{26}$ No obstante, Agulló Díaz destaca que en la década de los cincuenta ya comenzaron a concretarse una serie de medidas que ayudaron a «una tímida capacitación [femenina] en tareas agrícolas e industriales», ${ }^{27}$ aunque en NO-DO no se viese reflejado.

En la década de los sesenta, el gobierno franquista tuvo que aceptar la evidencia de que el número de trabajadoras continuaba aumentando y que la mujer trabajadora era una realidad, por lo que su interés en la capacitación profesional femenina también se vio ligeramente incrementado. A pesar de ello, las noticias y documentales que NO-DO emitía sobre estas enseñanzas se redujeron a las especialidades propias del sexo femenino: peluquería, arte, cerámica y artesanía. ${ }^{28}$ La inferioridad de la mujer con respecto al hombre también fue un tema al que recurrió NO-DO para justificar que, a pesar de que la mujer hubiese entrado en el ámbito público, el hombre seguía siendo superior y el único con capacidad para desenvolverse en ese espacio. Así, en un Noticiario emitido en 1964, que informaba sobre la clausura del curso de peluquería (mixto) del Taller-Escuela Técnico de Peluquería de Madrid, el locutor aludió a la mujer como un ser diferente y extraño con respecto al hombre que debía ser estudiado y analizado. «Desde muy antiguo, la cabeza

\footnotetext{
${ }^{26}$ En 15 de las 85 noticias, documentales y reportajes que proyectó NO-DO sobre este nivel educativo en los años cuarenta y los cincuenta se mostraba a las mujeres en estas especialidades de Formación Profesional y Enseñanzas Artísticas.

${ }_{27}$ Carmen Agulló Díaz, «De ignorada a necesaria: La formación profesional de las mujeres en el franquismo (1936-1975)», en Entre lo doméstico y lo público. Capacitación profesional de las mujeres rurales en España (1940-1977), ed. Sara Ramos Zamora (Madrid: Biblioteca Nueva, 2016), 55.

28 NO-DO proyectó 14 noticias, documentales y reportajes sobre la enseñanza profesional femenina, de las 69 noticias, documentales y reportajes que se emitieron sobre Formación Profesional en la década de los sesenta.
} 
de la mujer ha sido tema de laboriosos estudios, tanto por dentro como por fuera».29

En la primera mitad de los años setenta se produjo un aumento de las noticias ${ }^{30}$ que mostraban a las mujeres cursando especialidades femeninas y mixtas e, incluso, enseñanzas enfocadas a los hombres. No obstante, el discurso no varió, pues cuando la especialidad era femenina o masculina con presencia de mujeres, el narrador utilizaba un tono de burla o mofa con el que pretendía demostrar que la capacitación y la capacidad femenina no eran tan serias ni considerables como las masculinas. Sin embargo, en el caso contrario - hombres que cursaban especialidades calificadas como femeninas-, el narrador alababa el buen hacer de los alumnos transmitiendo a los espectadores que esas especialidades eran importantes y debían ser respetadas por el mero hecho de ser cursadas por hombres. En 1971, NO-DO proyectó una noticia ${ }^{31}$ sobre el Centro de Formación Profesional Acelerada «José Solís Ruiz» de Córdoba, pues se había convertido en un centro pionero al permitir la matriculación a las «señoritas que [deseasen] especializarse en algunas de las enseñanzas que en él se [cursaban]». «Las futuras operarias se [habían] inclinado, preferentemente, hacia las especializaciones de carácter electromecánico, de instalaciones eléctricas y también de pintura». En un momento dado, el narrador llegó a transmitir al espectador que el hecho de que las mujeres comenzasen a introducirse en el mundo establecido para los hombres era una forma de mantenerlas entretenidas, pues su capacidad intelectual no podía igualar o superar a la de sus compañeros varones y sus funciones, al final, primarían más que el trabajo, por lo que los estudios cursados se convertirían en meros adornos. El ejemplo más llamativo fue cuando la voz en off, tras mencionar que una de las especialidades seleccionadas por las alumnas era la de pintura, exclamó que la elección de esta profesión no debía «causar extrañeza, ya que, por instinto, las mujeres se pintan solas para todo». No obstante, finalizaba la locución destacando que este centro había producido un gran impacto en el mundo femenino cordobés y vaticinaba que,

\footnotetext{
${ }^{29}$ Noticiario $n .^{\circ} 1125 A(27 / 07 / 1964)$.

${ }_{30}$ NO-DO mostró 23 noticias, documentales y reportajes sobre la Formación Profesional femenina o mixta, de las 38 noticias, documentales y reportajes emitidos sobre la Formación Profesional en general en la primera mitad de los años setenta.
}

${ }^{31}$ Noticiario $n .^{\circ} 1506 A(15 / 11 / 1971)$. 
gracias a estas pioneras, «el número de matriculadas duplicará a las actuales $[\ldots]$ que por el momento se benefician con sus enseñanzas».32

\section{AUXILIO SOCIAL Y LA EDUCACIÓN DE LAS NIÑAS Y LAS JÓVENES A TRAVÉS DE NO-DO}

En el transcurso de la Guerra Civil española se fundaron, en ambos bandos, varias organizaciones para hacer frente a las necesidades de la población. Las más importantes fueron el Socorro Rojo en la zona republicana y Auxilio de Invierno en la zona nacional. Auxilio de Invierno, organización basada en la Winterhilfswerk alemana, fue creada en otoño de 1936 por Mercedes Sanz Bachiller - viuda de Onésimo Redondo - y Javier Martínez de Bedoya. Esta organización se expandió por otras regiones de España y fue reconocida por la autoridad militar por su labor de cuidado y ayuda a los más necesitados durante la contienda. En abril de 1937, Auxilio de Invierno pasó a denominarse Auxilio Social, convirtiéndose en la organización benéfico-asistencial más importante de esa época. Tal fue su importancia que el gobierno decretó la creación del Servicio Social femenino dependiente de esta organización. ${ }^{33}$ Finalizada la contienda, los objetivos de Auxilio Social cambiaron al centrar su misión en vencer la ignorancia y la miseria, la enfermedad, la mortalidad infantil y la delincuencia, así como para fomentar y ensalzar la educación religiosa y política según el nacional-sindicalismo en todos los ámbitos y momentos de la vida, no solo en las aulas. ${ }^{34}$ Estos objetivos se pretendían alcanzar a través de tres secciones (protección a la madre, protección al niño con familia y protección al niño huérfano) constituidas cada una por una serie de centros y de hogares.

Auxilio Social extendió por toda España sus diferentes instituciones entre las cuales figuraban las guarderías y los jardines maternales, y los hogares cuna, infantiles, escolares, de aprendizaje y profesionales, y de estudios medios y superiores. Anteriormente hemos explicado que el franquismo dejó a la mujer trabajadora, casada y con hijos, a la sombra

\footnotetext{
32 Noticiario $n .^{\circ} 1506$ A $(15 / 11 / 1971)$.

33 Ángela Cenarro Lagunas, La sonrisa de la Falange. Auxilio social en la guerra civil y en la posguerra (Barcelona: Crítica, 2005).

${ }^{34}$ Laura Sánchez Blanco, «Auxilio social y la educación de los pobres: del franquismo a la Democracia», Foro de Educación 10 (2008): 133-166. https://dialnet.unirioja.es/servlet/articulo?codigo=2906847.
} 
debido a que esta identidad femenina no era concebida en su discurso oficial. Sin embargo, Auxilio Social creó una serie de guarderías que fueron mostradas y publicitadas a través de nueve números de NO-DO. Las guarderías y jardines maternales eran centros destinados al cuidado de los niños y de las niñas - de entre 0-3 años en los primeros centros y de 3-7 años en los segundos- de madres trabajadoras y estaban ubicados en barrios obreros y zonas rurales. Su fin era convertirlos en personas sanas y fuertes a través de los cuidados hacia la salud, la instrucción religiosa, la alimentación, la gimnasia, en definitiva, a través de toda clase de cuidados que los más pequeños pudiesen necesitar. ${ }^{35}$

Los diferentes números de NO-DO que emitieron estas guarderías se caracterizaron por transmitir un mensaje de tranquilidad a las madres trabajadoras al presentar a las cuidadoras dispensando muestras de cariño y de afecto a los más pequeños, duchándolos, jugando con ellos, en definitiva, realizando todas aquellas actividades y acciones diarias que deberían desarrollar sus madres, llegando a mostrar, indirectamente, a la mujer como un ser que no cumplía con sus funciones por tener que trabajar fuera del hogar. No obstante, de las diez noticias y reportajes que proyectó NO-DO, solo tres se corresponden con la posguerra, el resto fueron emitidos a partir de mediados de los cincuenta y en los años sesenta, ${ }^{36}$ cuando el franquismo comenzó a ser consciente de que la mujer trabajadora, casada y madre, era una realidad y de que cada vez accedían más al mercado laboral, por lo que tenían que hacer propaganda de que el régimen sí se preocupaba por estas madres y sus hijos poniendo a su disposición una serie de centros donde podían dejarlos con la tranquilidad de que iban a recibir los mismos, o incluso mejor, cuidados que los dispensados por su propia madre.

En NO-DO encontramos un total de siete noticias y reportajes que proyectaron hogares infantiles y escolares, aunque solo cinco mostraron hogares construidos o adaptados para el aprendizaje de las enseñanzas femeninas. Los hogares de esta obra atendían tanto a los niños huérfanos como con familias en situación de pobreza. NO-DO mostró a las niñas

\footnotetext{
35 Noticiario $n .^{\circ} 39 A(27 / 09 / 1943)$.

${ }^{36}$ Noticiario n. ${ }^{\circ} 39 A$ (27/09/1943); Noticiario n. ${ }^{\circ} 546 A$ (22/06/1953); Revista de Imágenes $n .^{\circ} 611$ (01/01/1956); Noticiario n. ${ }^{\circ} 702 B$ (18/06/1956); Noticiario n. ${ }^{\circ} 815 A$ (18/08/1958); Noticiario $n .^{\circ} 887 A$ (04/01/1960); Noticiario n. ${ }^{\circ} 993 B$ (15/01/1962); Noticiario n. ${ }^{\circ} 1111 B$ (20/04/1964); y Revista de Imágenes La semilla: una obra de Auxilio Social (01/01/1965).
} 
asistiendo a clase mientras resolvían cuentas o escribían en pizarrines o en libretas, rezando, realizando una tabla de gimnasia o excursiones por el campo y ejecutando danzas tradicionales de España. ${ }^{37}$ En los hogares infantiles femeninos, las niñas — con edades comprendidas entre los 3 y 8 años- aparecían en un ambiente atractivo que les permitía olvidar las angustias, las penurias y las preocupaciones prematuras que no correspondían a su edad. ${ }^{38}$ Es decir, se mostraban los hogares como una familia donde los niños eran educados según los valores que el régimen consideraba que se debían enseñar en el hogar. Esta labor mostraba la incapacidad de algunas familias, sobre todo de las madres, pues sobre ellas recaía todo ese peso, de hacerse cargo de sus hijos, por lo que estos niños tenían que ser cuidados, alimentados y educados a través del "personal rector oportuno y también de guardadoras y empleados subalternos deliberadamente capacitados para esta delicada misión». ${ }^{39}$ Esto se presentaba como una delicada misión porque en sus manos tenían al futuro de la Patria y su deber era educarlos y cuidarlos, cuando no podía hacerlo su propia familia, de forma que pudiesen servir a España y al régimen cuando fuesen adultos.

Estos centros estaban regentados por congregaciones religiosas femeninas, aunque no fue hasta el nombramiento de Antonio María de Oriol y Urquijo, como delegado nacional de Auxilio Social (1957-1965), cuando las religiosas pudieron trabajar como cuidadoras. En algunos hogares infantiles y escolares había una maestra nacional - los hogares ubicados cerca de un pueblo o ciudad matriculaban a los niños y niñas en la escuela de dicha localidad - cuya función era iniciar a las pequeñas en la enseñanza a través de una «pedagogía desarrollada con paciencia y cariño» ${ }^{40}$ para favorecer la captación de la atención de las alumnas. Las niñas que asistían a los hogares escolares tenían entre 8 y 14 años, lo que, según el locutor de un número de NO-DO, permitía «una mejor asimilación de la enseñanza» enfocada en todo momento a desarrollar sus funciones como mujer. ${ }^{41}$

\footnotetext{
37 Revista de Imágenes n. 206 (01/01/1948); Noticiario n. ${ }^{\circ} 546$ A (22/06/1953).

38 Revista de Imágenes $n .^{\circ} 611(01 / 01 / 1956)$.

39 Revista de Imágenes n. 611 (01/01/1956).

40 Revista de Imágenes n. 611 (01/01/1956).

${ }^{41}$ Revista de Imágenes n. ${ }^{\circ} 611$ (01/01/1956).
} 
Esta adquisición y aprendizaje de las funciones y tareas que toda mujer debía saber hacer y conocer también fue transmitido en el único reportaje que NO-DO ${ }^{42}$ realizó sobre los hogares de aprendizaje y profesional. Las imágenes de NO-DO mostraron a las alumnas de un centro de iniciación profesional elaborando muñecas, confeccionando las prendas para los acogidos en la obra — por las que recibían un sueldo y primas por su trabajo-, aprendiendo a bordar, a coser y a escribir a máquina, y realizando una tabla de ejercicios gimnásticos y una exhibición de danzas, todo ello bajo la supervisión de las instructoras y cuidadoras que pertenecían a una orden religiosa. ${ }^{43}$ En estos hogares de iniciación profesional las muchachas cursaban las enseñanzas de administrativo y secretariado, trabajos que sí eran considerados aptos para el sexo femenino y que solían realizar, generalmente, mientras estaban solteras. La locución destacaba que las niñas se habían convertido en «mujercitas» y que se preparaban para incorporarse a la sociedad.

Los hogares femeninos de estudios superiores de Auxilio Social acogían a las futuras farmacéuticas, profesoras, licenciadas en ciencias o en derecho, etc., mientras cursaban sus estudios en la universidad o en las escuelas normales. ${ }^{44}$ A pesar de ello, el porcentaje de mujeres que accedían a estudios superiores era menor que el de los hombres y, además, tenían menos posibilidades que estos. NO-DO emitió tres números ${ }^{45}$ sobre estos centros, aunque no hemos encontrado ningún hogar femenino de estudios superiores, pero si hemos hallado uno sobre los hogares residencia femeninos en el que se acogía a muchachas de entre 14 y 21 años. Las acogidas en el Hogar Residencia Virgen de Montserrat (Barcelona) trabajaban y disfrutaban de una vida desprovista de un rigor excesivo, pero siempre bajo unas normas que les recordaban los «ineludibles conceptos de la moral y el deber». ${ }^{46}$ En estos hogares las muchachas podían modelar sus aspiraciones y elegir las ocupaciones que desempeñarían. También se les ofrecían las enseñanzas necesarias para su formación,

\footnotetext{
42 Revista de Imágenes La semilla: una obra de Auxilio Social (01/01/1965).

${ }^{43}$ Los hogares de Auxilio Social femeninos y mixtos que aparecían en NO-DO estaban regentados por órdenes religiosas femeninas.

44 Sánchez Blanco, «Auxilio social y la educación de los pobres», 148.

45 Noticiario n. ${ }^{\circ} 46$ A (15/11/1943); Revista de Imágenes n. ${ }^{\circ} 611$ (01/01/1956); y Revista de Imágenes La semilla: una obra de Auxilio Social (01/01/1965).

46 Revista de Imágenes n. ${ }^{\circ} 611$ (01/01/1956).
} 
es decir, una educación nacional-católica y enseñanzas propias de su sexo. A través de NO-DO el régimen publicitó la «gran» labor que realizaba en los hogares de Auxilio Social, cuidando y educando a las futuras generaciones que carecían de familia o que vivían en hogares no aptos para desarrollarse de manera óptima. Estas niñas permanecían bajo el amparo y el cuidado del régimen, desempeñaban un trabajo y se les seguía inculcando los valores y funciones propias de su sexo hasta que encontraban un marido con el que poder desempeñarlas de forma efectiva en su hogar.

\section{LA FEMINIDAD TRANSMITIDA POR LA SECCIÓN FEMENINA}

El 29 octubre de 1933 se celebró en el Teatro de la Comedia de Madrid un mitin que dio lugar a la fundación, unos meses después, de Falange Española. José Antonio Primo de Rivera fue su fundador y el encargado de desestimar la solicitud de su hermana Pilar Primo de Rivera y de otras cuatro muchachas más —Carmen, Inés y Dolores Primo de Rivera y Luisa María Aramburu - para afiliarse al partido. José Antonio se opuso a esta afiliación, pues «rechazaba toda idea de participación de las mujeres en la esfera pública, y particularmente en la actividad política concebida como pugna o combate viril en el que la violencia ocupa un lugar de primera importancia». ${ }^{47}$ Sin embargo, una serie de sucesos propiciaron que en julio de 1934 se crease la Sección Femenina de FET y de las JONS convirtiéndose Pilar Primo de Rivera en su jefe nacional. El cometido de esta organización era realizar las labores de propaganda, así como una serie de labores asistenciales que mantenían el respeto y la consideración hacia la mujer. ${ }^{48}$

La doctrina de Falange estaba fundamentada en restablecer las relaciones de género y en retornar a los valores sociales y religiosos que imperaban en España antes de que se proclamase la Segunda República. No obstante, estos ideales no habían sido erradicados por la República, ya

\footnotetext{
${ }_{47}$ Christine Lavail, «De la creación de la Sección Femenina (1934) a la campaña electoral de 1936: modalidades de intervención de las mujeres falangistas en la esfera pública», Arenal: Revista de historia de mujeres 15, no. 2 (2008): 348. https://dialnet.unirioja.es/servlet/articulo?codigo=3193918.

${ }_{48}$ Rosario Sánchez López, Mujer española, una sombra de destino en lo universal. Trayectoria histórica de Sección Femenina de Falange (1934-1977) (Murcia: Universidad de Murcia, 1990); y Estrella Casero, La España que bailó con Franco. Coros y Danzas de la Sección Femenina (Madrid: Editorial Nuevas Estructuras, 2000).
} 
que continuaban instaurados, aceptados y defendidos por la mayoría de la sociedad, aunque los falangistas se escudaran en que dichos ideales habían sido suprimidos y que su labor era volver a instaurarlos. José Antonio Primo de Rivera dijo poco sobre el tema de la mujer, aunque de manera clara y contundente: «el verdadero feminismo no debiera consistir en querer para las mujeres las funciones que hoy se estiman superiores, sino en rodear cada vez de mayor dignidad humana y social las funciones femeninas».49

Sección Femenina nació bajo la premisa de estos postulados, por lo que, a pesar de la integración de la mujer en la esfera pública, éstas vieron limitadas sus actividades a ciertos ámbitos y siempre como colaboradoras y facilitadoras de las actuaciones de la rama masculina. Esta supeditación al hombre es la que se encargó de transmitir al resto de españolas cuando, finalizada la guerra, le fue asignada la misión de instruir en el ámbito político y social a todas las mujeres españolas según los fines de Falange. El motivo por el que se encomendó esta misión a la Sección Femenina es que no aspiraba a cotas de poder ni era un elemento desestabilizador, pues en sus principios de subordinada, callada y abnegada labor no había cabida para eso. ${ }^{50}$ Estos eran los mismos principios que debían inculcar al resto de las mujeres junto con las funciones propias del sexo femenino: sumisión al hombre, cuidado del hogar y de los hijos, en ocasiones la labor asistencial, y ser una buena cristiana. Para alcanzar dicha misión se pusieron en marcha una gran cantidad de actividades enfocadas a cumplir las funciones educativas e identitarias encargadas por el nuevo régimen.

El Servicio Social femenino fue una de esas actividades, aunque en un principio dependió de la Delegación de Auxilio Social (1937-1939). En 1939, la dirección y organización de este servicio recayó sobre la Sección Femenina quien reestructuró la orientación formativa. NO-DO emitió un reportaje en el que explicaba que no solo los hombres tenían el deber de servir a la patria, pues «la mujer también [tenía] obligaciones patrióticas que [realizaba] a través del Servicio Social, mediante el cual

\footnotetext{
49 Sánchez López, Mujer española, 20.

50 Heliodoro Manuel Pérez Moreno, «La Sección Femenina de la España de Franco (1939-1975) y sus contradicciones entre "perfil de mujer" y medios educativos", Cadernos de História da Educaçao 7 (2008): 77-92. http://www.seer.ufu.br/index.php/che/article/view/1883.
} 
se [incorporaba] al servicio directo de España». Durante la Guerra Civil, las mujeres realizaban «las faenas más duras alegremente»y, finalizada la contienda, tenían la misión de reconstruir España «formando a las nuevas generaciones en un espíritu de entrega y servicio». ${ }^{51}$ El Servicio Social femenino se podía realizar por diversas modalidades. La modalidad ordinaria tenía una duración de seis meses y estaba dividido en dos fases: una formativa y una etapa de prestación. La realización de este servicio era obligatoria para todas las mujeres de entre 17 y 35 años que quisiesen obtener títulos académicos o el carnet de conducir, desempeñar un empleo retribuido, acceder a oposiciones, para las estudiantes universitarias, etc. Es decir, ese Servicio fue utilizado como moneda de cambio, pues el régimen obligaba a las mujeres a cumplirlo si querían acceder a determinados ámbitos, y así garantizar que aprendían su doctrina y el papel que se le había impuesto en la sociedad.

Mujeres alegres, trabajadoras en sus labores, con capacidad y actitud de ayuda al prójimo, serviciales, dóciles, sumisas, calladas, todos estos calificativos podrían resumir a la mujer que NO-DO presentaba y que se afanaba por cumplir el Servicio Social. NO-DO emitió dos reportajes en los que explicaba en qué consistía el Servicio Social femenino. La fase de formación duraba tres meses, se realizaba en las Escuelas Hogar de la Sección Femenina, en la Escuela de Mandos José Antonio (Castillo de la Mota), entre otros centros. En ellas las alumnas aprendían puericultura, cocina, socorrismo y primeros auxilios (anatomía y fisiología; vendajes; respiración artificial que ensayaban con un muñeco de goma; transporte del herido en camilla y a brazo; y salvamento a lo vivo dentro del agua), corte y confección (coser, tejer, tomar medidas, dibujar y cortar patrones sobre la tela, bordar, coser a máquina...), gimnasia, etc. «Dentro de estas escuelas las muchachas [hacían] sus propios servicios de comedor por turno riguroso» $\mathrm{y}$, tras la comida, disfrutaban de un rato de asueto, recreo y lectura, pero «sin descuidar la asistencia a los actos religiosos en la capilla».52

El periodo de prestación completaba al de formación y se realizaba en instituciones benéfico-sociales y asistenciales como guarderías, asilos, centros de Auxilio Social (comedores y hogares), hospitales, barrios

\footnotetext{
${ }^{51}$ Revista de Imágenes Servicio Social de la mujer (01/01/1965).

52 Revista de Imágenes Servicio Social de la mujer (01/01/1965).
} 
de inmigración, hogares maternales, centros de rehabilitación para niños y mayores y laboratorios — este espacio estaba destinado a las estudiantes de ciencias que desempeñaban su trabajo durante el Servicio Social como auxiliares de laboratorio-. El Servicio Social también se podía cursar en régimen de internado, aunque en este caso las enseñanzas duraban tres meses por ser más intensas. Finalizaba la locución destacando que el Servicio Social femenino era la actividad más importante realizada por la Sección Femenina, ya que a través de ella formaban a las mujeres españolas para que aprendiesen a realizar sus labores correctamente y se convirtiesen en seres útiles para la Patria. El narrador daba a entender que la mujer, antes de cursar el Servicio Social, no sabía realizar sus funciones de forma adecuada y que solo a través de esta formación adquiría todo lo que debía saber para realizarlas de manera eficaz. "Las mujeres españolas educan así su espíritu y completan su propia formación al mismo tiempo que se hacen útiles a la colectividad nacional».53

La labor de la Sección Femenina no finalizaba con el Servicio Social, pues una de sus actividades más emblemáticas fue la capacitación de las mujeres campesinas, ya que para el franquismo «la formación de la mujer campesina [era] un problema de gran interés y transcendencia para la mejora moral y económica de los pueblos y de las aldeas españolas», ${ }^{54}$ al considerar que su trabajo en todo lo relacionado con la agricultura, la ganadería, etc., era una extensión de sus funciones como mujer. Esta capacitación en el ámbito rural se realizó a través de diversas actividades entre las que destacaron las Cátedras Ambulantes —creadas en 1946-, aunque esta misión también instruyó a hombres y niños. La Sección Femenina creó las Cátedras Ambulantes como centros de formación itinerantes que recorrían los pueblos de toda la geografía española con menos de 5.000 habitantes para «mejorar las condiciones culturales, materiales, profesionales, cívicas, y de espíritu comunitario del campesinado, exigiendo de los individuos una adaptación y reorganización social tanto individual como colectiva». ${ }^{55}$ Las instructoras de las Cátedras

\footnotetext{
53 Revista de Imágenes Servicio Social de la mujer (01/01/1965).

${ }^{54}$ Revista de Imágenes n. ${ }^{\circ} 843$ (01/01/1961).

55 Sara Ramos Zamora, «Iniciativas de educación no formal para las mujeres rurales (1939-1975)», en Entre lo doméstico y lo público. Capacitación profesional de las mujeres rurales en España (19401977), ed. Sara Ramos Zamora (Madrid: Biblioteca Nueva, 2016), 126.
} 
recorrían los rincones más apartados de la geografía española, lejos de su hogar y soportando las inclemencias meteorológicas, para proporcionar «útiles enseñanzas adaptadas a las características de cada región». ${ }^{56}$ Para conocer estas características acudían casa por casa para hablar con los habitantes y así saber cuáles eran sus necesidades. ${ }^{57}$

Las Cátedras permanecían entre 30-45 días, aproximadamente, en cada pueblo y estaban formadas por cuatro o cinco camiones-remolque acondicionados para diversos fines: un camión vivienda para las monitoras; un remolque cocina; un camión para sala de estar y exponer los trabajos; un remolque-clínica con rayos X; y dos remolques que se podían convertir en aula. Las Cátedras estaban formadas por un equipo fijo constituido por una jefe de cátedra, una profesora de corte y confección, una profesora de labores y trabajos manuales, una instructora rural, una instructora de juventudes y una divulgadora sanitario-social. ${ }^{58} \mathrm{~A}$ este equipo se podía sumar una enfermera o divulgadora rural, profesores de Cámaras Agrarias, una profesora de cocina y camaradas del SEU. ${ }^{59}$ NO-DO emitió nueve números sobre las Cátedras Ambulantes. Las imágenes de los noticiarios, documentales y reportajes que transmitieron esta labor destacaban por mostrar dos realidades yuxtapuestas. La realidad de los pueblos donde los habitantes y sus viviendas presentaban un aspecto desaliñado, mal cuidado, estaba en contraposición con las instructoras, que iban bien arregladas, impolutas, con un aspecto bien cuidado, y con los remolques, sobre todo el de cocina que destacaba por la limpieza, como si nunca hubiese sido utilizado. Estas imágenes podían provocar en la mujer campesina y en el resto de las mujeres de clases populares un ideal inalcanzable, al ver el rol de mujer falangista bajo un halo de perfección y de pulcritud.

Las enseñanzas que impartían a las mujeres campesinas eran todas aquellas que capacitaban a la mujer para realizar las funciones que el

\footnotetext{
56 Revista de Imágenes n. ${ }^{\circ} 770$ (01/01/1959).

57 Revista de Imágenes n. ${ }^{\circ} 822$ (01/01/1960).

58 Miguel Lacruz Alcocer, Entre surcos y pupitres. Historia de la Educación Agraria en la España de Franco (Madrid: Endymion, 1997).

59 Pilar Rebollo Mesas, "Viaje al centro de ninguna parte: historia de las Cátedras Ambulantes», en Las escalas del pasado: IV Congreso de Historia Local de Aragón (Barbastro, 3-5 de julio de 2003), coords. Alberto Sabio Alcutén y Carlos Forcadell Álvarez (Huesca: Instituto de Estudios Altoaragoneses; Barbastro: UNED, 2005), 281-288. https://dialnet.unirioja.es/servlet/articulo?codigo=1215945.
} 
régimen establecía como propias de su sexo, más aquellas que las formaban para desarrollar las tareas del campo de una forma óptima: puericultura, industrias rurales (curtido y confección de pieles), cocina, conservería, economía doméstica, buenos modales (a todos los campesinos les enseñaban buenos modales y maneras y a las mujeres, además, las instruían sobre cómo poner la mesa, hacer un buen uso de los cubiertos y a atender el servicio de comedor), enseñanzas del hogar (labores y trabajos manuales, corte y confección), cultura general (los hombres asistían a estas enseñanzas por la noche cuando finalizaban sus tareas en el campo), etc. ${ }^{60}$

«Con las niñas se sigue el plan general de juventudes para toda clase de enseñanzas». ${ }^{61}$ La instructora de música era la encargada de enseñar a las pequeñas los pasos de la danza mientras se cumplía una de las funciones más importantes de la Sección Femenina, la conservación y recuperación del folklore nacional. La instructora de gimnasia las iniciaba en la gimnasia rítmica con el objetivo de formar mujeres sanas y fuertes capaces de realizar sus funciones naturales como madre, esposa, cristiana y, en este caso, campesina. Los niños y niñas también eran instruidos en la enseñanza de la religión católica. Estas enseñanzas también eran impartidas por las instructoras a niñas de entre ocho y diecisiete años en los albergues de verano de la Sección Femenina. En estos albergues, las alumnas seguían unas rutinas y una disciplina muy marcada y aprendían a convivir en camaradería, entendimiento, compenetración, hermandad y confianza. Las actividades que más destacaban eran la misa y la oración de la mañana y de la noche, así como la gimnasia, las excursiones, la música, la danza, realizar el servicio de comedor...; en definitiva, actividades que pretendían acercarlas a la naturaleza y favorecer su desconexión, descanso y hermanamiento, mientras les inculcaban los valores del régimen.

Según Scanlon, «el propósito de la Sección Femenina [...] no era meramente el de educar a las muchachas y mujeres que habían ingresado voluntariamente en la organización y aceptaban su programa; éstas constituían la élite cuya tarea era adoctrinar al resto de la población

\footnotetext{
${ }^{60}$ Revista de Imágenes n. ${ }^{\circ} 698$ (01/01/1958); Revista de Imágenes n. ${ }^{\circ} 822$ (01/01/1960).

${ }^{61}$ Revista de Imágenes $n$. $^{\circ} 698$ (01/01/1958).
} 
femenina». ${ }^{62}$ Para poder instruir a todas las mujeres de España, la Sección Femenina debía comenzar preparando a sus propios mandos. La formación de los mandos y de las instructoras se impartió en diferentes escuelas. NO-DO elaboró 33 números, repartidos entre sus diferentes secciones, donde se mostraron, principalmente, la Escuela Mayor de Mandos José Antonio (Medina del Campo, Valladolid), la Escuela Nacional Isabel la Católica (Navas del Marqués) y la Escuela Nacional de especialidades Julio Ruiz de Alda (Madrid), aunque también se emitieron noticias, documentales y reportajes de otros centros donde se formaban a las futuras mandos e instructoras. ${ }^{63}$

La misión principal de la Escuela de Mandos José Antonio era «la formación de los mandos nacionales y provinciales de la Sección Femenina de FET y de las JONS».64 Esta institución pretendía ser la casa matriz donde las afiliadas viviesen la domesticidad característica de un verdadero hogar y familia falangista, a pesar de que esta experiencia se vivía a una escala mayor en la que no había hombres, por tanto, la realidad que vivían estas muchachas era muy diferente a la que se vivía en un hogar. Estas escuelas, según Kathleen Richmond, eran una «invención del hogar y la vida familiar, una teatralización de ciertos hábitos y funciones inherentes a la «misión trascendental» de las mujeres como constructoras de hogares». ${ }^{65}$

El locutor de uno de los reportajes que presentó la Escuela Mayor de Mandos José Antonio explicaba que «los estudios, en clases teóricas y prácticas, abarcan todas las disciplinas necesarias para quienes han de ejercer puestos de responsabilidad».66 Estas disciplinas no solo pretendían capacitar a los futuros mandos, sino también formar a las mujeres

\footnotetext{
62 Geraldine M. Scanlon, «La mujer bajo el franquismo», Tiempo de Historia 27 (1977): 9-10. http:// www.tiempodehistoriadigital.com/resbcombinada.php?autor=Scanlon,\%20Geraldine\%20M.\&inicio $=0 \&$ paso $=10 \&$ orden $=$ Titulo.

63 Escuela de Mandos Reyes Católicos (Almería); Escuela de Mandos Ramiro Ledesma Ramos (Peñaranda de Duero); Granja-Escuela Hermanas Chabás (Valencia); Escuela Emilia Pardo Bazán (Bastiagueiro); Escuela de Jerarquías de la Ciudad Lineal; y Escuela Nacional de Educación Física femenina Julio Ruiz de Alda (Madrid).

${ }^{64}$ Revista de Imágenes n. ${ }^{\circ} 906$ (01/01/1962).

65 Kathleen Richmond, Las mujeres en el fascismo español. La Sección Femenina de la Falange, 19341959 (Madrid: Alianza, 2004), 96.

${ }^{66}$ Revista de Imágenes n. 906 (01/01/1962).
} 
en sus funciones naturales, ya que cuando se casasen abandonarían su labor en la Sección Femenina para pasar a cuidar de su marido, su hogar y sus hijos. Las materias comunes para todas las alumnas eran religión, nacionalsindicalismo, organización, puericultura, convivencia social, pedagogía, música, historia, arte, literatura, matemáticas, además de otras enseñanzas que complementaban las materias específicas de cada servicio: cultura general, enseñanza del hogar (cocina y repostería), corte y confección, muñequería, etc. Además, la disciplina era un pilar básico que se puede encontrar en las imágenes de NO-DO, pues a través de ellas vemos a las futuras mandos vivir en un ambiente casi militar, donde había unas rutinas muy instauradas, y donde las muchachas mostraban movimientos y comportamientos muy mecánicos y estudiados que las hacían parecer soldados, pero que a la vez transmitían delicadeza y armonía.

La misión de la Escuela Nacional Isabel la Católica era preparar «a las instructoras de juventudes adiestrando a las que tendrán luego a su cuidado a las niñas de España». ${ }^{67}$ Este centro constaba de una escuela de magisterio privado cuyo plan de estudios era el mismo que el de las Escuelas oficiales de Magisterio. Las enseñanzas que se impartían eran economía doméstica y hogar, trabajos manuales, música y danzas de España, gimnasia y deportes. Estas instructoras eran las encargadas de impartir las materias de nacionalsindicalismo, gimnasia y música en los colegios femeninos. Las muchachas que asistían a la Escuela de Mandos José Antonio y a la Escuela Isabel la Católica seguían la misma orientación cultural, religiosa, política y disciplinaria. En uno de los reportajes el locutor explicaba que las actividades rutinarias desempeñadas por las alumnas pretendían asemejar a las labores de un ama de casa. ${ }^{68} \mathrm{La}$ rigidez en el horario, el perfecto cuidado tanto de las alumnas como de las dependencias y las normas de estas instituciones completaban la identidad de estos centros que asemejaban, más que a un hogar, a un cuartel, aunque las imágenes y la locución de NO-DO intentasen suavizar este aspecto. Las actividades/rutinas que realizaban las muchachas diariamente consistían en la oración de la mañana y de la noche, el servicio de comedor, excursiones, participación en las fiestas y acontecimientos del

\footnotetext{
67 Revista de Imágenes $n .^{\circ} 770(01 / 01 / 1959)$.

${ }^{68}$ Revista de Imágenes n. 906 (01/01/1962).
} 
pueblo, ejercicios gimnásticos, etc. El cambio de actividad era anunciado con el toque de la campana.

La gimnasia, la música y la danza tuvieron una gran presencia en NO-DO, pues el adecuado desarrollo físico y mental de la mujer era un tema principal para la Sección Femenina. La presencia de los deportes y de la gimnasia en la vida de la mujer no estaba relacionada con la formación de futuras deportistas profesionales, sino con una concepción higienista, ya que una mujer sana traería más hijos al mundo y dispondría de una buena salud para cuidarlos. ${ }^{69}$ Este motivo es el que propició el interés de NO-DO por todas aquellas actividades, competiciones, ejercicios, etc., que estuviesen vinculadas con la gimnasia femenina. Uno de los temas más recurrentes en NO-DO fueron las exhibiciones gimnásticas y de danzas realizadas por grupos femeninos cuando Franco, su esposa Carmen Polo u otras autoridades nacionales y extranjeras visitaban alguna institución o asistían a algún acto. Los noticiarios y documentales, que NO-DO emitió en diferentes secciones, ${ }^{70}$ mostraron a las niñas, jóvenes y adultas ejecutando tablas de ejercicios de gimnasia rítmica con o sin aparatos, saltos en el plinto o en el potro, equilibrio en la barra, realizando algunos deportes, etc., que les conferían delicadeza, perfección y homogeneidad al ejecutar los ejercicios de forma compasada y al vestir todas iguales - pololos negros y anchos hasta la rodilla donde se cernían con una goma o pantalón corto, camisas de manga corta de color blanco y zapatillas y calcetines también de color blanco-. Estas demostraciones gimnásticas representaban una prueba fidedigna de que la labor encomendada a la Sección Femenina para formar mujeres sanas y fuertes se estaba cumpliendo en todos los rincones de España y con todas las mujeres, independientemente de su clase social y edad.

Una demostración de que uno de los pilares fundamentales de la educación franquista se estaba cumpliendo fueron los cinco números que NO-DO emitió sobre la Escuela Julio Ruiz de Alda donde se formaban las futuras instructoras de educación física. Este centro fue promocionado en NO-DO, transmitiendo a la población, y en especial a las mujeres, que

\footnotetext{
${ }^{69}$ Gonzalo Ramírez Macías, «El Franquismo Autárquico, la Mujer y la Educación Física», Historia Social y de la Educación 3, no. 1 (2014): 78-102. http://www.redalyc.org/pdf/3170/317030572004.pdf.

${ }^{70}$ Noticiario $n .^{\circ} 8$ (22/02/1943); Noticiario n. ${ }^{\circ} 17$ (26/04/1943); Noticiario n. ${ }^{\circ} 76$ A (12/06/1944); Noticiario $n .^{\circ} 253 B(10 / 11 / 1947)$; Noticiario $n . .^{\circ} 748 A(06 / 05 / 1957)$.
} 
su formación gimnástica recaía sobre profesionales bien formadas e instruidas. La Escuela Nacional de especialidades Julio Ruiz de Alda fue creada en 1957 y ubicada en un edificio de la Ciudad Universitaria de Madrid que era comúnmente conocido como La Almudena. Este centro contaba con cuatro escuelas de hogar, educación física, Asistentes Técnico Sanitarios y Asistentes Sociales en las que, a su vez, se impartían diversas especialidades, aunque la especialidad de educación física fue en la que se centró NO-DO. NO-DO emitió un reportaje muy completo en la sección Imágenes del Deporte ${ }^{71}$ en el que explicaba que la Escuela Julio Ruiz de Alda constituía "la parte femenina del INEF.72 Centro reconocido para la formación y perfeccionamiento de este profesorado femenino de acuerdo con la Ley de Educación Física promulgada en diciembre de $1961 » .{ }^{73} \mathrm{El}$ locutor de este reportaje continuaba destacando la gran labor realizada por la Sección Femenina de forma callada y tenaz a través de este centro y de los diversos cursos que, desde 1940, han formado a las instructoras de esta materia. "Gracias a esta tarea puede asegurarse que el conocimiento de la educación física ha llegado hasta la última aldea de nuestro país. Salud, belleza y fuerza forman trípode común de toda la educación física» ${ }^{74}$

Las materias tenían estipuladas un número de horas semanales y las alumnas tenían que escoger, «de forma obligatoria y optativa, una especialidad, en cuyo caso la instrucción [era] más intensa». ${ }^{75}$ En la escuela se prestaba especial atención a los juegos, y la natación era, según el narrador, «uno de los deportes donde con mayor fuerza brilla[n]» los principios de salud, belleza y fuerza. Sin embargo, la natación fue uno de los deportes que más controversias despertó en el seno de la Iglesia, pues contravenía algunos de los principios de la moral católica. ${ }^{76}$ No

\footnotetext{
${ }^{71}$ Imágenes del Deporte titulado Imágenes del Deporte 74 - Escuela Nacional De Educación Física (01/01/1975).

72 Instituto Nacional de Educación Física (INEF).

${ }^{73}$ Imágenes del Deporte titulado Imágenes del Deporte 74 - Escuela Nacional De Educación Física (01/01/1975).

${ }^{74}$ Imágenes del Deporte titulado Imágenes del Deporte 74 - Escuela Nacional De Educación Física (01/01/1975).

75 Imágenes del Deporte titulado Imágenes del Deporte 74 - Escuela Nacional De Educación Física (01/01/1975).

76 María Luisa Zagalaz Sánchez, «La educación física femenina durante el franquismo: La sección femenina», Apunts: Educación física y deportes 65 (2001): 6-16. https://www.revista-apunts.com/es/ hemeroteca? article $=534$.
} 
obstante, la Sección Femenina, a pesar de acatar esta moral, buscaba poder llevar a la práctica aquellos deportes que creía imprescindibles para lograr su misión. La natación fue uno de esos casos, pues las competiciones femeninas de natación no tenían que ser muy promocionadas para que asistiese el menor número de público y, además, las muchachas tenían que llevar un bañador con una falda y utilizar albornoz, pues el decoro era característica esencial de toda niña y mujer. ${ }^{77}$ A pesar de ello, la Sección Femenina promocionó este deporte para atraer a las juventudes y algunas competiciones femeninas de natación fueron filmadas por NO-DO, así como a las futuras instructoras de educación física practicando este deporte, aunque cabe destacar que la natación femenina, en comparación con otros deportes y los ejercicios gimnásticos, fue uno de los menos emitidos por NO-DO y siempre intentando mostrar a las muchachas el menor tiempo posible en traje de baño. Al igual que la natación fue un deporte aceptado para ser realizado por las mujeres, el franquismo vetó otros deportes que no eran aptos para el sexo femenino y seleccionó otros que si eran válidos desde la óptica de la moral y desde la perspectiva técnica (hockey, esquí, baloncesto y balonmano, sumándose a esta lista el voleibol en 1952 y el atletismo en 1961) y que fueron proyectados por NO-DO.

Otra actividad impulsada por la Sección Femenina fueron los grupos de Coros y Danzas. Estos grupos fueron creados con el fin de conservar y mantener el folklor tradicional de las regiones españolas. ${ }^{78}$ Estos grupos tuvieron una gran aceptación por parte de la sociedad y por el régimen. Los jóvenes veían en ellos una forma de entretenimiento y de poder viajar y conocer otras regiones o países, mientras que para el régimen se convirtieron en un instrumento con el que recopilar y perpetuar la música y danzas de antaño, sobre todo a través de los concursos, y con los que promocionarse, pues pronto el franquismo comprendió que estos grupos tenían capacidad de traspasar las fronteras, sobre todo durante la etapa de autarquía y aislamiento internacional vivida en la posguerra, y de mostrar al mundo la cara más afable de la dictadura. ${ }^{79} \mathrm{Al}$ igual que las exhibiciones gimnásticas, las demostraciones de danzas

\footnotetext{
77 Zagalaz Sánchez, «La educación física femenina».

${ }^{78}$ Noticiario $n .^{\circ} 31 A(02 / 08 / 1943)$.

79 Casero, La España que bailó con Franco.
} 
fueron utilizadas para recibir y dar la bienvenida a los diplomáticos, dirigentes y otras autoridades extranjeras que visitaban España, así como para inaugurar o clausurar actos oficiales y congresos nacionales e internacionales. Todos estos actos fueron recogidos en NO-DO donde, además, se proyectaron los concursos de Coros y Danzas organizados por la Sección Femenina, las exhibiciones de estos grupos tanto en los actos organizados por el franquismo como en los de la propia organización femenina, y los viajes que realizaron al extranjero. ${ }^{80}$ Las bailarinas, principalmente mujeres, aunque en ocasiones también bailaban hombres, iban ataviadas con trajes regionales, al igual que los miembros de los coros y de las rondallas, que en este caso sí solían ser, en su mayoría, hombres.

\section{CONCLUSIONES}

NO-DO fue una de las ventanas más importantes del franquismo para transmitir su doctrina y por la que los españoles debían mirar y nutrirse de ella. Por este motivo hemos utilizado NO-DO con el objetivo de conocer y analizar aquellos noticiarios, documentales y reportajes que mostraron la educación, instrucción y adoctrinamiento de las mujeres y como esas noticias también servían para afianzar la identidad femenina del franquismo. Tras analizar el contenido de NO-DO sobre la educación femenina y contrastarlo con las fuentes secundarias podemos destacar que este organismo no captó una identidad femenina, sino cuatro. Las mujeres habían pasado de tener unos derechos y libertades a dar un paso hacia atrás y volver al rol que tradicionalmente se le había asignado.

NO-DO mostró que las mujeres debían ser buenas amas de casa y esposas, cuidar a sus hijos y a su marido, y ser abnegadas, calladas, obedientes, así como gozar de buena salud para poder cumplir con todas sus tareas. Para este último punto se recurría a enseñanzas de cocina, gimnasia, hábitos de higiene, costura, etc. Estos conocimientos no solo les serían útiles para ellas, sino para todos los miembros de su familia, pues su deber era darse a los demás, asumir la labor asistencial. Esta identidad, este papel, se inculcaba a las mujeres desde que eran pequeñas en las

\footnotetext{
${ }^{80}$ Noticiario $n .^{\circ} 6(08 / 02 / 1943) ;$ Noticiario $n .^{\circ} 45 A$ (08/11/1943); Noticiario n. ${ }^{\circ} 96 A$ (30/10/1944); Noticiario $n .^{\circ} 291$ B (02/08/1948); Noticiario $n .{ }^{\circ} 351$ B (26/09/1949); Noticiario n. ${ }^{\circ} 487 B$ (05/05/1952); Noticiario $n^{\circ} 1175 A(12 / 07 / 1965)$.
} 
guarderías, colegios y centros benéfico-asistenciales y así era reflejado en NO-DO, destacando esta herramienta como otro medio educativo para enseñar a las niñas esa identidad cuando asistían a las salas de cine. Las niñas aprendían y veían en la gran pantalla como otras niñas también aprendían a coser, a fabricar muñecas, a realizar ejercicios gimnásticos para fortalecer el cuerpo y la mente, y a bailar danzas tradicionales de España.

NO-DO mostraba todo esto a los españoles haciendo que estas concepciones no solo fuesen interiorizadas por las mujeres, sino también por los hombres. Sin embargo, desde finales de la década de los cincuenta, cuando España comenzó a salir del periodo de la posguerra, de la autarquía y del aislamiento, NO-DO mostró otra realidad femenina, la de las mujeres trabajadoras que estaban casadas y tenían hijos, pero que tenían que salir a trabajar fuera del hogar porque la situación así lo requería. Esta realidad fue presentada en NO-DO a través de las guarderías, ya que eran el sitio idóneo donde las madres podían dejar a sus hijos porque eran donde mejor iban a estar cuidados y atendidos y así lo hacía saber NO-DO. Sin embargo, esta identidad fue la menos transitada, pues la sumisión al hombre las obligaba a trabajar en caso de necesidad en el hogar y siempre que sus tutores (marido, padre, hermano/s...) les diesen permiso.

Otra identidad femenina transmitida por NO-DO fue la de las mujeres que trabajaban para la Sección Femenina. Éstas, en general, estaban solteras, no tenían hijos, leían, estudiaban, viajaban. En uno de los Noticiarios se alababa el buen hacer de las afiliadas de la Sección Femenina destacando los valores - abnegada, callada, laboriosa, atenta, servicial, entregada- que debían regir la vida de toda mujer y que ellas debían enseñar, pero también manifestar, pues eran ejemplo de ellos, aunque su modo de vida difiriese al del resto de mujeres españolas. «El quehacer de la Sección Femenina ha sido lección de ejemplaridad de conducta, de entrega al servicio y de renuncia a la vanidad» asistiendo a todos «los lugares donde su presencia era necesaria. Estas mujeres han hecho entrega generosa de su trabajo y de su esfuerzo sin regatear sacrificios». ${ }^{81}$ Por último, la vida dedicada a Jesús, al cristianismo, era otra de las vías a la que podían acceder y que les permitía desempeñar un trabajo,

${ }^{81}$ Noticiario $n .^{\circ} 882 A(30 / 11 / 1959)$. 
generalmente benéfico-asistencial, como se puede comprobar en algunos números de NO-DO, sobre todo en aquellos que mostraron hogares femeninos y mixtos de Auxilio Social.

\section{Nota sobre la autora}

María Dolores Molina Poveda es graduada en Educación Infantil (2015) con un Máster Universitario en Cambio Social y Profesiones Educativas (2016). Actualmente está cursando los estudios de Doctorado en Educación en la Universidad de Málaga. Su tesis doctoral trata sobre la educación vista a través de NO-DO (1943-1981) y sus principales líneas de investigación son el uso crítico de imágenes (fijas y en movimiento) como fuente y como objeto de estudio en Historia de la educación, centrándose especialmente en cómo mostraba NO-DO las actividades educativas formales y no formales. Así mismo, junto a este medio propagandístico, estudia otras fuentes como publicaciones periódicas de diversa índole que aportan perspectivas distintas al estudio de la historia de la política educativa y de la cultura escolar. Además, es miembro de la Sociedad Española de Historia de la Educación (SEDHE).

\section{REFERENCIAS}

Agulló Díaz, Carmen. «De ignorada a necesaria: La formación profesional de las mujeres en el franquismo (1936-1975)». En Entre lo doméstico y lo público. Capacitación profesional de las mujeres rurales en España (1940-1977), editado por Sara Ramos Zamora, 45-72. Madrid: Biblioteca Nueva, 2016.

Balletbó, Anna. «La mujer bajo la dictadura». Leviatán 1, no. 8 (1982): 90-101. https://prensahistorica.mcu.es/es/consulta/registro.cmd?id=1028530

Casero, Estrella. La España que bailó con Franco. Coros y Danzas de la Sección Femenina. Madrid: Editorial Nuevas Estructuras, 2000.

Cenarro Lagunas, Ángela. La sonrisa de la Falange. Auxilio social en la guerra civil y en la posguerra. Barcelona: Crítica, 2005.

Cenarro Lagunas, Ángela. «Identidades de género en el catolicismo, el falangismo y la dictadura de Franco (presentación)». Historia y política: Ideas, procesos y movimientos sociales 37 (2017): 17-26. https://recyt.fecyt.es/index. $\mathrm{php} /$ Hyp/article/view/58381/35664

Falcone, Rosa. «Género, familia y autoridad. Sociedades patriarcales y comunidades contemporáneas». Revista Científica de UCES XVI 1 (2012): 67-73. 
http://dspace.uces.edu.ar:8180/xmlui/bitstream/handle/123456789/1465/Genero_familia_Falcone.pdf?sequence $=1$

Lacruz Alcocer, Miguel. Entre surcos y pupitres. Historia de la Educación Agraria en la España de Franco. Madrid: Endymion, 1997.

Paz Rebollo, María Antonia y María Inmaculada Sánchez Alarcón. «La historia filmada: los noticiarios cinematográficos como fuente histórica. Una propuesta metodológica». Filmhistoria online 9, no. 1 (1999): 17-33. http://revistes.ub.edu/index.php/filmhistoria/article/view/12366

Pérez Moreno, Heliodoro Manuel. «La Sección Femenina de la España de Franco (1939-1975) y sus contradicciones entre "perfil de mujer" y medios educativos». Cadernos de História da Educaçao 7 (2008): 77-92. http://www.seer. ufu.br/index.php/che/article/view/1883

Rabazas Romero, Teresa y Sara Ramos Zamora. «La construcción del género en el franquismo y los discursos educativos de la Sección Femenina». Encounters on education = Encuentros sobre educación = Recontres sur l'éducation 7 (2006): 43-70. https://dialnet.unirioja.es/servlet/articulo?codigo $=4683187$

Ramírez Macías, Gonzalo. «El Franquismo Autárquico, la Mujer y la Educación Física». Historia Social y de la Educación 3, no. 1 (2014): 78-102. http://www. redalyc.org/pdf/3170/317030572004.pdf

Ramos Zamora, Sara. «Iniciativas de educación no formal para las mujeres rurales (1939-1975)». En Entre lo doméstico y lo público. Capacitación profesional de las mujeres rurales en España (1940-1977), editado por Sara Ramos Zamora, 73-113. Madrid: Biblioteca Nueva, 2016.

Rebollo Mesas, Pilar. «Viaje al centro de ninguna parte: historia de las Cátedras Ambulantes». En Las escalas del pasado: IV Congreso de Historia Local de Aragón (Barbastro, 3-5 de julio de 2003), coordinado por Alberto Sabio Alcutén y Carlos Forcadell Álvarez, 281-288. Huesca: Instituto de Estudios Altoaragoneses; Barbastro: UNED, 2005. https://dialnet.unirioja.es/servlet/articulo?codigo $=1215945$

Richmond, Kathleen. Las mujeres en el fascismo español. La Sección Femenina de la Falange, 1934-1959. Madrid: Alianza, 2004.

Rodríguez Martínez, Saturnino. El NO-DO: catecismo social de una época. Madrid: Editorial Complutense, 1999.

Sánchez-Biosca, Vicente. «NO-DO y las celadas del documento audiovisual». Cahiers de civilisation espagnole contemporaine 4 (2009): 1-7. http://roderic. uv.es/bitstream/handle/10550/29172/059791.pdf?sequence=1\&isAllowed=y

Sánchez-Biosca, Vicente. «NO-DO, icono del franquismo». Letra internacional 88 (2005): 29-38. http://roderic.uv.es/handle/10550/29197

Sánchez Blanco, Laura. "Auxilio social y la educación de los pobres: del franquismo a la Democracia». Foro de Educación 10 (2008): 133-166. https:// dialnet.unirioja.es/servlet/articulo?codigo $=2906847$ 
Sánchez Blanco, Laura. «El boletín de Auxilio Social. La formación de las mujeres que trabajaban en el servicio social (1937-1939)». Papeles Salmantinos de Educación 17 (2013): 101-120. https://summa.upsa.es/viewer.vm?i$\mathrm{d}=0000032528$ \&page $=1$ \& search $=$ \&lang $=$ es\&view $=$ main

Sánchez López, Rosario. Mujer española, una sombra de destino en lo universal. Trayectoria histórica de Sección Femenina de Falange (1934-1977). Murcia: Universidad de Murcia, 1990.

Scanlon, Geraldine M. «La mujer bajo el franquismo». Tiempo de Historia 27 (1977): 4-28. http://www.tiempodehistoriadigital.com/resbcombinada.php?autor=Scanlon,\%20Geraldine\%20M.\&inicio=0\&paso=10\&orden=Titulo

Sorlin, Pierre. Cines europeos, sociedades europeas 1939-1990. Barcelona: Paidós Comunicación, 1996.

Terrón Abad, Eloy. «Coeducación y control social en la España de la Posguerra». Revista de educación 326 (2001): 185-194. http:/www.educacionyfp. gob.es/dam/jcr:c17dc2c6-e377-4a04-a2d1-68893f9adb3c/re32611-pdf.pdf

Tranche, Rafael R. y Vicente Sánchez-Biosca. NO-DO. El tiempo y la memoria. Madrid: Cátedra/Filmoteca Española, 2018.

Vilanova Ribas, Mercedes y Xavier Moreno Juliá. Atlas de la evolución del analfabetismo en España de 1887 a 1981. Madrid: Ministerio de Educación Cultura y Deporte, 1992. https://sede.educacion.gob.es/publiventa/detalle.action? $\operatorname{cod}=1403$

Zagalaz Sánchez, María Luisa. «La educación física femenina durante el franquismo: La sección femenina». Apunts: Educación física y deportes 65 (2001): 6-16. https://www.revista-apunts.com/es/hemeroteca? article=534 